\title{
O dia que o interesse venceu a ética na televisão brasileira
}

Fernando Campos*

Os jornalistas são donos de uma grande responsabilidade na sociedade moderna. Os profissionais do meio de comunicação são os responsáveis por manter as pessoas bem informadas e ainda possuem o poder da mudança nas mãos. Para que o trabalho seja feito da forma mais justa e correta, a ética do jornalismo precisa ser lembrada por todos os que estão envolvidos com o produto final que será apresentado para o público. Não se pode esquecer que sua ação pode prejudicar alguém de alguma forma e é inadmissível que uma atitude só vise o benefício próprio ou de uma empresa que se trabalha. É necessário que o profissional de jornalismo tenha noção da responsabilidade da sua atuação e que ele apure minuciosamente uma informação que será propagada. A sociedade tem direito à informação correta, sem interesses de terceiros.

Para analisar sobre casos de falta de ética no jornalismo brasileiro, resolvi falar sobre o conhecido 'Caso Eloá' e como a apresentadora Sônia Abrão, da emissora RedeTV! na época, fez a cobertura do sequestro. $\mathrm{Na}$ análise vou relacionar algumas atitudes da jornalista com os códigos de ética do jornalismo.

O 'Caso Eloá' aconteceu em 2008 em Santo André-SP. Um rapaz chamado Lindemberg manteve sua ex-namorada Eloá em cárcere privado, sob a mira de uma arma e de frequentes ameaças por 100 horas. Quero mostrar nesse trabalho como a mídia acabou influenciando diretamente no final trágico daquele triste acontecimento, já que a menina Eloá terminou sendo assassinada.

Apresentadora do programa 'A tarde é sua', da RedeTV!, a jornalista Sônia Abrão sempre foi conhecida pela exploração do sensacionalismo na televisão e no 'Caso Eloá' não foi diferente. Sem se preocupar com as consequências dos seus atos, Sônia resolver ultrapassar todos os limites da ética para conseguir audiência para o seu programa e emissora.

A produção do programa conseguiu o telefone de Lindemberg, o sequestrador, e o colocou ao vivo no 'A tarde é sua'. Isso mesmo, Sônia Abrão entrevistou o rapaz no meio de um sequestro e expôs tudo para o Brasil inteiro. Essa atitude inicial já fere um artigo do código de ética do jornalismo. Quando se fala do direito à informação, se ressalta que a liberdade de imprensa implica com o compromisso com a responsabilidade social inerente à profissão. Quando se entrevista um sequestrador e uma vítima ao vivo, em um momento de pressão e tensão, fica claro que não existe nenhuma preocupação com o que essa atitude pode gerar na cabeça dos envolvidos. A responsabilidade social passou longe do momento, tendo em vista que vários especialistas já declararam que essa atitude da Sônia Abrão influenciou diretamente no fim trágico do caso. Isso porque a ação pressionou e confundiu o sequestrador, prejudicando diretamente as negociações com a polícia militar.

\footnotetext{
* Aluno do curso de Comunicação Social, período 2014.2.
} 
A conduta profissional do jornalista também foi esquecida pela apresentadora. Quando se faz uma entrevista, evidente que o entrevistado é considerado uma fonte. Um dos códigos de ética mais conhecido deixa claro que o jornalista não deve colocar em risco a integridade das fontes e dos profissionais com quem trabalha. Na minha visão, quando você entrevista e pressiona um sequestrador para conseguir "informações", você está colocando a vida do mesmo e dos outros envolvidos em risco. Isso porque já existe uma situação com alto grau de tensão e que pode, com essa exposição nacional, gerar uma atitude impensada de Lindemberg.

Mas os erros não param por aí. Outro ponto que não foi levado em consideração pela profissional foi o respeito ao direito à intimidade, à privacidade, à honra e à imagem do cidadão. É possível se observar isso quando Sônia Abrão faz perguntas sem nenhuma relevância informativa para o público, como por exemplo: "O que o sequestrador conversou com Eloá sobre o relacionamento afetivo deles?".

Os dois principais erros que vão completamente contra os códigos de ética do jornalismo vão ser abordados agora. Fica muito claro no artigo 7 que o jornalista não pode expor pessoas ameaçadas, exploradas ou sob risco de vida. No 'Caso Eloá', Sônia Abrão entrevista a menina sequestrada e que está sendo, frequentemente, ameaçada por Lindemberg. Essa pressão e esse aumento de tensão colocam a vida da garota e do rapaz em risco, isso porque o caso tem alto grau emocional e ainda envolve a ação da polícia do lado de fora do apartamento.

Um jornalista não pode divulgar informações de caráter mórbido, sensacionalista ou contrário aos valores humanos, especialmente em cobertura de crimes e acidentes. O que se viu no programa 'A tarde é sua' foi exatamente o contrário e esse foi o maior problema da cobertura do caso. Pensando somente na audiência, Sônia Abrão entrevistou um sequestrador e uma vítima por meia hora no seu programa. Não é assim que se faz jornalismo. Ela desrespeita a polícia e age como uma negociadora de sequestros no incidente. Mostro aqui um pequeno trecho da ação incorreta da apresentadora: "Vamos terminar com isso na boa Lindemberg. Você não é mal e nunca foi. Libera a Eloá, se libera e vamos resolver tudo isso. É tanta gente que ama vocês sofrendo aqui do lado de fora. Vamos botar um ponto final nessa história".

Sem capacidade para fazer a negociação, Sônia influenciou negativamente no desfecho da situação. Especialistas em negociações de reféns da polícia apontaram inúmeros erros na ação da jornalista. Um deles aconteceu quando ela fala sobre familiares dos envolvidos, o que normalmente deixa os sequestradores sempre mais nervosos. Outro ponto criticado chega ser até óbvio. Com a longa entrevista, ela deixa o telefone do sequestrador ocupado e impede o trabalho da polícia e dos especialistas no caso.

O que vimos nesse episódio deve ser lembrado para sempre e deve ser utilizado nas faculdades para mostrar para os futuros profissionais do meio como não se faz jornalismo. $O$ jornalismo precisa ser justo, o jornalismo tem uma grande responsabilidade na sua atuação e seus profissionais precisam levar a informação para a sociedade de forma sensata e honesta. $A$ apresentadora Sônia Abrão não pensou na gravidade da atuação e explorou uma tragédia para 
aumentar sua audiência e para dar lucro para a sua emissora. Foi completamente amadora e irresponsável, se achou acima do bem e do mal, e não teve a sensibilidade suficiente para deixar a polícia trabalhar para salvar os envolvidos no sequestro.

\section{Links da entrevista da Sônia Abrão:}

http://www.youtube.com/watch?v=9 gSLc0oCic - Parte 1

http://www.youtube.com/watch?v=CGJewjnPejA - Parte 2

http://www.youtube.com/watch?v=F4fBo PGXWM - Parte 3 